\title{
THE BEGINNINGS OF CIVIL SERVICE REFORM.
}

\author{
[I have been asked to write an article for ThE YALE LAw Journal. I \\ have not time to prepare a proper legal article, but may add a little variety to \\ its columns.]
}

About three years ago I read in one of our magazines a very interesting article from the pen of Theodore Roosevelt, entitled: "Seven Years of Civil Service Reform." It was written soon after his retirement from the office of Civil Service Commissioner, and gave an account of the civil service during his term in that office. I thought then that an article of some interest might be written upon the first efforts for, and the beginning of, civil service reform in this country. I cannot hope to write so interesting an article as Governor Roosevelt; but, as I happened to be in Congress during the time when the first efforts were made for a reform of the civil service, I have thought that an article upon this subject might be of some interest. The present system of civil service reform dates from the law of I883. known as the Pemberton Bill, passed during the administration of President Arthur. I presume many in this generation do not know of the attempts that were made fifteen years earlier to inaugurate a civil service reform in this country, and the failure of the project at that time.

For the first forty years of our history the evils of partisan appointments in the civil service were wholly unknown. During all the administrations from that of George Washington to President John Quincy Adams, inclusive, no removals from office were made for political reasons. The number of those engaged or employed in the civil service of the government was very small then compared with the number at the present time. In 1802 there were only 2,622 persons in the civil service. In 18 i 7 there were only 5,608 . The number gradually increased with the growth of the country from that time onward until I86I, when the War of the Rebellion broke out. At the close of that war there were over 50,000 persons in the civil service of the government. It was not until the administration of Andrew Jackson, in 1829 , that the rule was adopted that "to the victors belong the spoils." John Quincy Adams, during his administration of the four years before that time, had made it a rule to make no removals whatever for political reasons, but only for cause. General Jackson, in the first month of his administra- 
tion, made more removals from office than had been made before during the forty years of our history. Parton, in his Life of Jackson, states that it was claimed that during the first year of the presidency of General Jackson 2,000 persons were removed from the civil employment of the government, and 2,000 partisans of the President appointed in their stead, and he says himself, that "though the exact number cannot be ascertained, I presume it was not less than 2,000." Martin Van Buren, who succeeded General Jackson as president, was charged with being responsible in great measure for this change in the policy of the government, and friends of his, like Swartwout in New York, were appointed in place of honest men who had long proved their ability and integrity in the offices they held. Swartwout was appointed Collector of the Port of New York, and stigmatized his administration of that office by the defalcation of nearly a million of dollars. When Van Buren was ap. pointed Minister to England by Jackson in $183^{2}$, one of the most serious charges made against him on the floor of the Senate was this, that he had been instrumental in degrading the civil service by removals and political appointments in that service. Henry Clay and Daniel Webster both attacked him in their speeches, and the Senate rejected him as Minister to England; but he was that year elected Vice President, and was elected President four years later. From that time until after the War of the Rebellion, the rule became established under the different administrations, that the friends and partisans of the President were entitled to the offices in the civil service.

At the close of the War of the Rebellion at Appomattox there were a million of soldiers in the field to be disbanded, and to return to private life. The necessities of the war had made a great increase in the civil service, especially in the departments at Washington, and there were a much larger number in the civil service at that place than were necessary before that time. A reduction of force in some of the departments became necessary; and at the same time there were many discharged soldiers seeking places in the civil service of the government, and the disposition was to give them the precedence in appointments to office, other things being equal. This condition of the civil service soon attracted the attention of thinking men in Congress, and out of it; and during the Thirty-ninth Congress, the first to meet after the close of the war, a joint select committee was raised, styled the Joint Select Committee on Retrenchment. This committee were instructed to inquire, among other things, into the expenditures in all the branches 
of the service of the United States, and report whether any and what offices ought to be abolished; and also to consicler the expediency of so amending the laws under which appointments to the public service was made as to provide for the selection of subordinate officers by proper boards. Nothing was accomplished during that Congress, but in the Fortieth Congress a resolution was passed reviving and continuing the Committee on Retrenchment; and at a meeting of that committee, July 20 , r867, the whole matter was referred to a sub-committee, consisting of Senators Williams and Patterson and Representative Jenckes.

Hon. Thomas A. Jenckes, above referred to, a distinguished lawyer of the state of Rhode Island, and a member of Congress from 1865 to $r 87$, inclusive, was the real father of the system of civil service reform in this country. He seems to have done pretty much all the worls of the sub-committee; and on the 25 th of May, 1868 , he made an exhaustive report for the committee to the House of Representatives, accompanied by a bill to carry into effect the committee's recommendations. That Congress failed to take action on the bill, and at the beginning of the Forty-first Congress a Select Committee on the Reorganization of the Civil Service of the Government was appointed, and Mr. Jenckes was made its chairman. At the same time a Joint Select Committee on Retrenchment was appointed by the Senate, but Mr. Jenckes went on with his work without regard to the Senate Committee; and I think the committees never met with each other, as committees of the two Houses seldom meet in joint session. Car1 Schurz, then a Senator from Missouri, was a member of the Senate Committee on Retrenchment. Though he has talked and written a good deal about civil service reform in late years, I never knew of his doing anything in that line while he was in the Senate, that was of any practical benefit. The result of Mr. Jenckes' labors in the Fortyfirst Congress was the passage of the law, approved March 3, I87 , authorizing the President to prescribe such regulations for the admission of persons into the civil service of the United States as may best promote the efficiency thereof, and authorizing him to appoint a commission, or employ suitable persons to conduct inquiries as to the fitness of those seeking to enter the civil service. A law had previonsly been passed, on the $3^{\mathrm{d}}$ of March, r865, declaring that persons honorably discharged from the military or naval services, by reason of disability resulting from wounds or sickness incurred in the line of duty, should be preferred for appointments to civil offices, provided 
they had the proper capacity for the discharge of the duties of such offices.

President Grant was heartily in favor of the proposed reform in the civil service. His second annual message of December 5, 1870, contained the following passage:

"Always favoring practical reforms, I respectfully call your attention to one abuse of long standing which I would like to see remedied by this Congress. It is a reform in the civil service of the country. I would have it go beyond the mere fixing of the tenure of office of clerks and employees who do not require 'the advice and consent of the Senate' to make their appointments complete. I would have it govern, not the tenure, but the manner of making all appointments. There is no duty which so much embarrasses the Executive and heads of departments as that of appointments, nor is there any such arduous and thankless labor imposed on Senators and Representatives as that of finding places for constituents. The present system does not secure the best men, and often not even fit men, for public place. The elevation and purification of the civil service of the Government will be hailed with approval by the whole people of the United States."

It was largely owing to his influence and recommendation that the law of March 3, $187 x$, was passed.

On the igth of December, $x 871$, President Grant sent a special message to Congress stating that in accordance with the law of March 3, he had convened a commission of eminent gentlemen to advise rules and regulations for the purpose of reforming the civil service, and he transmitted their report with his message. Those rules were to take effect Janwary $\mathrm{I}, \mathrm{I} 872$. He stated in his message that there was no appropriation for continuing the Board after that year, and recommended that a proper appropriation be made to continue their services for another year. He said in that message, "I ask for all the strength which Congress can give me to enable me to carry out the reforms in the civil service recommended by the commisson, and adopted to take. effect, as before stated, on January 1, 1872 ." An appropriation was made of $\$ 15,000$, I think, for salaries of the commissioners and for the expenses of their office for another year.

Hon. George Wm. Curtis, the eminent and elegant author and man of letters, was chairman of the Civil Service Commission appointed by President Grant. He resigned the office after a brief period and Dorman B. Eaton of New York was appointed in his stead. The Civil Service Commission con- 
sisted of seven member, the chairman and three or four others receiving a compensation or salary fixed by the President. Some of the commission served without pay.

Hon. William D. Kelly, for many years a distinguished Representative in Congress from Philadelphia, was appointed chairman of the Civil Service Committee in the House in the Forty-second Congress. Mr. Kelly was a very busy member of the Committee of Ways and Means, the leading committee in the House; and I think he gave very little time to the Civil Service Committee. I do not think he made a report from that committee during the whole Congress, but the appropriation for the expenses of the Civil Service Commission was continued during that Congress.

Upon the organization of the Forty-third Congress, I found myself appointed chairman of the Committee on Civil Service. I had never been a member of that committee, and had not been identified with the project in any manner; and it was an appointment that I did not seek or expect. There were some strong men on the committee, including Gen. Stewart L. Woodford of New York, Gen. Benjamin F. Butler of Massachusetts, General Hurlbut of Illinois, and others. The next morning I went to the chairman of the Committee on Accounts, who, under the rules, had the control of such matters, and asked to have a room assigned for the committee. He replied that we did not need any room and that there was no room to spare; that the committee in the last Congress had done nothing, and there was no need of a room for us. I also asked for authority to appoint a clerk, and was told that the committee did not need any clerk; and that the clerk in the Fortysecond Congress had had nothing to do except to act as private clerk for the chairman. I called his attention to the resolution creating the Civil Service Committee some years before, which in express terms authorized a clerk. The reply was, that the committee might have a needed clerk in the first place, but there was no need of any now. I met General Butler on the floor of the House a few moments afterwards, and he asked me when I was going to call the committee together. I replied that the committee seemed to be without a local habitation, even if it had a name. I had served with General Butler on the Judiciary Committee in a previous Congress, of which committee he was now chairman. He kindly offered the use of his committee room for our meeting on any day when his own committee was not in session. I thereupon called a meeting of the committee at as early a date as possible in the Judiciary 
Committee room. When we met, all the members being present, I soon found out that seven members out of eleven, headed by General Butler, were deadly opposed to the whole project of civil service reform. General Butler took the ground that the whole thing was a fraud, and that they should cut off the appropriation and stop the whole business. All the Democratic members of the committee and half of the Republicans agreed with him. The only men that I could rely upon for any action in its favor were General Stewart L. Woodford, Mr. Willard of Vermont, and Mr. Willard of Michigan. I took good care not to have any vote taken; but after a general talk upon the subject by the members, the committee adjourned subject to the call of the chairman. I went to Speaker Blaine immediately after and asked him if he knew what sort of a committee he had made up for the reform of the civil service. He replied with a twinkle in his eye and his usual magnetic expression of face that he thought he did, and asked me if he had not given me some pretty strong men for members of the committee. I told him that I thought he had, and that they were altogether too strong, and that seven out of the eleven were opposed to the whole thing. He said in reply that he thought he had represented the sentiment of the House in the committee, as he had formed it. I told him that might be all true, for all the Democratic members and half or more of the Republicans seemed to be against it; but that it wasn't a very pleasant committee to be made chairman of, when it was so constituted that we could do nothing whatever. I confess that I went into the House one morning about this time determined to resign my place as chairman of the committee, but while waiting for an opportunity to do so, I reflected upon the fact that the Speaker might make it very unpleasant and uncomfortable for me during the whole Congress, if I declined an appointment he had given me. A member might not be recognized or given any chance for the floor during the whole Congress, unless the Speaker chose to recognize him. The Speaker was as much of a czar then as he has been in Congress since that time; and it is essential that he should be so, as events since have shown that the business of the government in the House could never be accomplished without autocratic authority. Judge E. R. Hoar, of Massachusetts, who sat by my side in that Congress, used to say of the Speaker, that he was the "Almighty up in that chair." I concluded, therefore, that it would be better discretion to say nothing about it, and did not carry out my intended purpose; but I 
did not like to be left in the position of a chairman of a committee who could do nothing. I therefore went to the three Democratic members of the committee, with whom I was on very pleasant personal relations, and said to them in substance like this: You are in the minority, and are not responsible for the action of this House, but I want a personal favor of you, for I don't want it said that our Civil Service Committee has killed this whole project of civil service reform. I want you, as a personal matter, to vote with me, at the next meeting of the Committee, in favor of recommending an appropriation for the continuance of the Civil Service Commission, and then let the Committee on Appropriations and the House take the responsibility. After some demurring, each one of the Democratic members agreed to vote with me in committee as a personal favor, though they said they thought the whole thing a humbug. Having secured this pledge, I called a meeting of the committee very soon after, and to General Butler's astonishment, when the vote in committee was taken, it was found that the committee recommended a continuance of the appropriation for the Civil Service Commission. I remember General Butler's remarks on the occasion, some of which were quite vigorous. He said to me, "Kellogg, what do you want to do this thing for? The whole matter is an infernal humbug." I replied that what previous service I had had in legislative bodies before coming to Congress was in the Connecticut Legislature, and that I had made it a rule in case of questions of public interest where there was a great division of sentiment, to give the House a chance to vote upon it, and not strangle it in the cradle. "Well," says General Butler, "if one of my family had a colored baby, I would strangle it as soon as I could get to the cradle." In accordance with the vote of the committee, we made our fecommendation for the continuance of the appro priation to keep alive the Civil Service Commission. The recommendation went to the Committee on Appropriations, under the rules of the House, as that committee at the time was the only committee authorized to report appropriations to the House. It was strangled in that committee and never saw the light. No report was ever made upon it, and James A. Garfield was chairman of that committee. I think he was personally in favor of civil service reform, but a majority of his committee were evidently of an opposite opinion. An amendment was put on an appropriation bill to repeal the law, but it failed of passage between the House and Senate.

Under a resolution of the House early in the Forty-third Congress, the Committee on Civil Service were directed to 
inquire into the condition of the departments in Washington. We had no clerk of the committee, as I have said, but a subcommittee was appointed to do the work, of which I was chairman. The Treasury Department seemed to be the one that the House desired to have especially examined. There had been no organization of the Treasury Department by law for something like forty years. It had grown to be an immense department compared with its condition prior to the War of the Rebellion. There were thousands employed in it where hundreds had been employed before the war. It had grown up by accretion, as I might call it; that is, by appropriations from year to year for the new and enlarged work of the department which the war had created. There was no warrant of law back of the appropriations in its organization. The whole of the internal revenue business, the whole of the immense work growing out of the national currency and the issuing of bonds and the work of engraving and printing, and many other portions of the department, were directly attributable to the exigencies of the war. I went to the Treasury Department and began my inquiries. I spent over a year in the investigation and in the preparation of a bill, and went through that vast establishment from turret to foundation. The Secretary of the Treasury, then the Hon. Benjamin $H$. Bristow, of Kentucky, was heartily in favor of a reorganization by law; and as I had no clerk of the committee, he kindly assigned a very competent clerk in the Treasury Department to assist me in the work. I found among other things that the salaries of the most important officers at the heads of the various bureaus and divisions were altogether too sma11. They had been fixed years before the war, when the expense of living in Washington was not half as great. The most efficient officers in the department, as well as in other places of the government, often resigned because they could do better in private life. For an example, the Hon. Gustavus V. Fox was Assistant Secretary of the Navy during the whole four years of the Civil War, and performed a Herculean amount of work at that time. His salary was $\$ 3,500$ per annum, and he resigned soon after and went to Lowell, Mass., as superintendent of a manufactory, at $\$ 7,000$ a year. One of the most valuable and efficient cashiers in the U.S. Treasury was about to resign while I was doing my work in the deparment. His salary was $\$ 2,800$ a year, and he was offered nearly twice that amount as cashier of a bank. A slice of $\$ 1,000$ was taken off of the "slush fund," so called, and added to his salary in order to 
retain him in the department. The "slush fund" that I speak of was a name given to a lump appropriation that had been made in Congress after the war, for the purpose of dividing it among the chiefs of divisions and the important officers in the Treasury Department. It had amounted to something like $\$ 300,000$ a year at one time during President Johnson's administration, but it had now been reduced to a little over $\$ 30,000$ a year. It was the wrong way to pay officials, of course, for their salaries should be fixed by law. The men who received it, as they jokingly said, used to go to the trough in the Secretary's office to get their share of the "slush," and the division of it was never entirely satisfactory. After months of investigation I prepared a bill for reorganization of the department. It abolished the lump sum that I have spoken of and raised the salaries of the chiefs of bureaus and divisions and the important men in the department, some thirty or forty in number. If I remember correctly, there had been twentythree divisions in the office of the Secretary during President Johnson's administration, and they were reduced to twelve. At the same time, by cutting off useless officers, and reducing the force where the Secretary said it would not injure the service, there was $\$ 200,000$ annually saved to the government by the terms of the bill as stated by the Secretary. The bill was reported to the House and passed in spite of the opposition to the increase of salaries. It went to the Senate and was there laid on the table, with the suggestion that they might raise a committee of their own to investigate the subject. I knew what that meant, and that the bill would never see the light again if left in that way. Watching my opportunity I succeeded in getting a two-thirds vote of the House to suspend the rules so as to make it in order to offer the bill as an amendment to the Sundry Civil Appropriation Bill, and it was attached to that bill by vote of the House; and in that manner it became a law. It has remained the law of the Treasury Department ever since, except that a modification of some part of it was made by a law called the "Dockery Bill" a few years ago. The committee also reported and procured the passage of a bill reorganizing the civil portion of the War Department and effected, as the Secretary said, a large saving there. I ought to say that there was a good system of examinations for admission and promotion of clerks in the Treasury Department, and in some of the other departments, before any Civil Service Commission was ever created.

The law of 1873 still remained upon the statute book, but the Civil Service Commission, having no appropriation to carry 
on its work, died from starvation. President Hayes, who succeeded President Grant, was heartily in favor of some system of civil service reform, and urgently advocated it in his inaugural address and his first message to Congress; but Congress for several years turned a deaf ear to the whole matter. It was not revived again until after the assassination of President Garfield, when the project of civil service reform was renewed, and resulted in the law of 1883 , under which a new Civil Service Commission was established. It is difficult for people to understand at this day how strong the sentiment against such a system of civil service was in Congress twenty-five years ago. At the time the first Civil Service Commission existed, it was made a matter of ridicule; and such men as the genial S. S. Cox, of New York, used to enjoy hurling their shafts of ridicule and sarcasm at the whole system, which they called the "Chinese system," coming down from early generations. The press of the country, with few exceptions, was either indifferent, or joined in the clamor and ridicule against it. The columns of the New York Tribune during the second administration of President Grant were full of sneers and sarcasm at the atttempts of civil service reform under his administration; but the Tribune was then a wandering sheep and did not love the fold of the Republican party. It had gone off in the Greeley campaign of 1872, and did not return to its former place in the Republican party until after the Hayes campaign of 1876 .

It is not the purpose of this article to discuss the merits of this civil service reform system. Its only purpose is to show the efforts that were made years ago to establish it and their failure. Civil service reform has come to stay; for the sentiment of the people would undoubtedly revolt against an entire abolition of it. It has certainly relieved members of Congress of a vast amount of thankless and unpleasant work; but to make the best civil service for the government something more than a literary or educational civil service examination is necessary. A man may pass the best examination, and be the laziest and most inefficient clerk in the department. The civil service has been extended, and persons in the employment of the government appear in the classified force by thousands, which were never intended to be included in the law when it was passed. Officers in the service of the government who are obliged to give bonds for the honesty of those employed under them, ought to have something to say about their appointment. The Collector of Internal Revenue, who is obliged to give bonds for the honesty and faithfulness of his deputies, ought to have some voice in 
their selection. The justice of this has been recognized, I think, in a recent order that clerks and employees in our post offices in the classified service shall hereafter give bonds for the1r own honesty and integrity. There have been some sweeping orders bringing thousands of persons into the classified service without much regard to whether it would improve the service or not. A drag net was stretched over something like 30,000 employees of the government in the closing months of the last administration by a single order, the intention of which was apparent. The tendency is to increase the civil service in numbers far beyond the wants of the government. There is always a rush to get into the service, and those who have passed the requisite examinations are clamoring to get in; and when once in it is not as easy to remove inefficient and incompetent persons as it used to be. There is not usually a great stimulus to energetic and efficient work in the service, when a clerk or employee feels that he has the blanket of civil service reform thrown over him to keep him in his place. From the statistics furnished from time to time, I think the number in the civil service of the government has increased much more rapidly since the passage of the civil service act than before. There were only about 60,000 officers and persons in the civil service of the United States, according to the Blue Book in I 873 , and it was reported last year in Washington that there were over 178,000 in the civil service; an increase, if those figures are correct, which far outruns the increase in the population of the United States. There are strong reasons why the head of a bureau or division in a department should have the power to remove a lazy and inefficient clerk without regard to the excellence of his educational certificate. There are many other elements beside the mere educational qualification that make a man's fitness for a civil service position. No private business corporation in the world could run their business with an edu. cational certificate for their employees, without regard to their efficiency and fitness for their places in other respects. The most efficient persons should be retained in the civil service, and those who do their work the best, without regard to their politics.

There is one branch of the civil service that has never been brought in under the present system, or any other, for the purpose of showing their fitness for the places. I refer to the foreign civil service of this country. Of course our ambassadors, ministers and high officials abroad are expected to be selected from our most eminent men, and this has been the usual rule in 
all administrations; but there are a large number of consuls and officials sent from this country to all the nations of the globe, and these have been considered to this day mere political appointments, and they are usually made chiefiy for real or supposed political services. Men are sent abroad as consuls to nations of whose language they have not the slightest knowledge; and by the time they have learned the language and have become somewhat acquainted with their duties they are turned out and a new set appointed by a new administration. This is all wrong. If there is any branch of our civil service that requires trained and efficient men who can best serve their country abroad, it is our foreign civil service. Great Britain is far in advance of us in this respect. She has had a class trained for foreign service many years. Our commercial interests and relations with other nations are growing rapidly the round world over. Men should be appointed to those places abroad for their fitness and their ability to promote the best interests of their own country, without regard to their politics; and they should be kept in their official positions, or promoted to other official positions abroad, according to their fitness, without danger of being removed at every change of administration. The march of events has brought our country the present year into new relations with the whole world. Whether we desired this state of things to come or not, it has come; and our foreign service in the future will be much more important to the interests and prosperity of this country than it has been in the past. After military government of our new possessions has ceased, the crucial test of our success in the government of these new possessions will come. There are honest differences of opinion as to the success of a new policy for our government. Those opposed to any increase of our territory beyond our limits on our own continent insist that we can never succeed in governing distant colonies. England has succeeded, and its greatness as a power in the world is largely in its colonies. Even little Holland has governed successfully thirty millions or more of Malays for years past without serious trouble; and the American nation ought to be able to form a suitable government for eight million Malays. Those who oppose the acquisition of any territory brought to us by the fortune of the recent war say that it is contrary to the policy of our government from its foundation, and to the Monroe Doctrine as enunciated nearly eighty years ago. The policy of our government as to expansion has been pretty well established by our action during the whole century from the time of 
Jefferson. As to the Monroe Doctrine, it has no more relevance to the presennt state of things than the Levitical Law of Moses. That doctrine was enunciated in regard to the revolted Spanish colonies in Central and South America alone. It was uttered as a warning to the "Holy Alliance," so-called, of the continental powers of Europe, which threatened to aid and assist Spain in restoring her monarchial authority over her revolted colonies on this continent; and that was all that the much talked of Monroe Doctrine meant at the time. Pessimists as to the future of this great government may flood the country with anti-expansion literature; eminent but faint hearted statesmen may dream of calamities to come, and proclaim their fearful forebodings of the evils of the extension of our authority to islands in distant seas. All such should turn for consolation to the words of the good old hymn:

"Ye fearful souls, fresh courage take, The clouds you so much dread

Are big with mercies, and may break In blessings on your head."

For one, I have an abiding faith that the Anglo-Saxon race on this side of the Atlantic will prove itself as capable of successfully governing colonies in the uttermost parts of the sea, as England and Holland have done during the present century.

S. W. KELLOGG. 